\title{
UJI KECEPATAN SESAAT MELALUI GERAK PARABOLA MENGGUNAKAN SOFTWARE TRACKER PADA PERMUKAAN GESEK
}

\author{
Muhamad Fasha Nurfauzan', Santi' ${ }^{1}$ Sarah Nur Rahmawati', Marnita Geptia Sari1 \\ 1 Program Studi Pendidikan Fisika, Fakultas Tarbiyah dan Keguruan, UIN Sunan Gunung \\ Djari Bandung, Indonesia \\ E-mail: mfashanurfauzan@gmail.com
}

\begin{abstract}
ABSTRAK
Penelitian ini menguji kecepatan sesaat pada sebuah sistem bola tipis berongga yang menggelinding pada bidang lengkung tanpa kecepatan awal. Percobaan dilakukan dengan mengubah kekasaran bidang lintasan lengkung yang dilalui bola. Lintasan pertama memiliki kekasaran yang lebih besar daripada lintasan kedua yang nilai koefien gesek dapat diabaikan. Percobaan ini dilakukan dengan menganalisa titik jatuh bola sebagai sumbu x dan titik pelepasan bola sebagai sumbu y secara analitik dan ekperimental. Secara eksperimen yaitu dilakukan dengan cara melepaskan bola dari puncak bidang lengkung dan menandai titik jatuh bola saat sampai ke dasar. Gerakan bola selama meluncur direkam menggunakan video recorder handphone, lalu dianalisis menggunakan software traker. Pengolahan data dilakukan melalui proses manual menggunakan rumus gerak parabola, hukum kekekalan energi mekanik. Sofware tacker sendiri berfungsi sebagai analisis vidio pada setiap tracket. Selanjutnya menbandingkan nilai kecepatan relatif pada kedua sistem yaitu bidang kasar dan bidang licin. Hasil percobaan menunjukan bahwa.lintasan licin memiliki kecepatan sesaat lebih besar daripada kecepatan sesaat pada lintasan kasar. Dengan nilai secara pehitungan lintasan licin 1,431 m/s dan lintasan kasar 1,323 m/s. Sedangkan dengan menggunakan tracker nilai kecepatan sesaat pada gerak parabola di lintasan licin adalah $1,712 \mathrm{~m} / \mathrm{s}$ dan di lintasan kasar adalah $1,589 \mathrm{~m} / \mathrm{s}$.
\end{abstract}

Kata kunci: Energi mekanik, gerak parabola, tracker

\begin{abstract}
This study tested instantaneous velocity on a hollow thin ball system that rolled on a curved plane without early velocity. The experiment was done by changing the roughness of the curved trajectory that the ball traversed. The first path has a roughness greater than the second path that the Coefien string value can be ignored. This experiment was conducted by analyzing the ball falling point as $X$ axis and the release point of the ball as a $Y$ axis in analytic and ecperimental. Experimentally it is done by releasing the ball from the top of the curved plane and marking the falling point of the ball when it got to the bottom. Movement of the ball during slide recorded using mobile video recorder, then analyzed using Traker software. Data processing is done through the manual process of using parabola motion formula, the Law of eternity of mechanical energy. Sofware Tacker itself serves as a vidio analysis on each tracket. Next compares the relative velocity values on both systems i.e. rough fields and slippery fields. The results of the experiment showed that. The slippery track has a instantaneous velocity greater than the instantaneous velocity on the rough trajectory. With a slippery track count of $1.431 \mathrm{~m} / \mathrm{s}$ and a rough trajectory of $1.323 \mathrm{~m} / \mathrm{s}$. Whereas by using a tracker the speed value of a moment on the motion of the parabola in the slippery track is $1.712 \mathrm{~m} / \mathrm{s}$ and in the rough trajectory is $1.589 \mathrm{~m} / \mathrm{s}$.
\end{abstract}

Keywords: mechanical energy, parabolic motion, tracker

DOI: http://dx.doi.org/10.15575/jtlp.v3i1.6546

Received: 12 Juli 2018 ; Accepted: 30 Agustus 2018 ; Published: 1 September 2018 


\section{PENDAHULUAN}

Penelitian dalam buku Experiment and Video Analysis in Classical Mevhanics halaman 129 142, telah membahas bahwa kecepatan sesaat sebuah bola yang menggelinding pada permukaan lengkung dengan ketinggian tertentu dapat dilakukan dengan menggunakan tiga cara. Pertama uji saat bola menggelinding melalui lintasan alat, kedua menggunakan sistematika gerak proyektil (parabola) saat bola mulai jatuh, terakhir menggunakan analisis video dengan ketinggian pelepasan bola yang berbeda pada alat. Namun pada penelitian tersebut hanya menggunakan lintasan yang sama sehingga tidak diketahui pengaruh dari kekasaran lintasan tersebut. Berdasarkan kekurangan tersebut, peniliti mencoba menguji kecepatan sesaat dengan lintasan yang mempunyai kekasaran berbeda.

Kecepatan yang dimaksud adalah titik dimana bola mulai terjatuh pada lintasan lengkung yang berada pada ketinggian tertentu. Saat bola mulai jatuh maka lintasan bola akan membentuk gerak parabola yang gaya hambat udara diabaikan. Untuk mencari kecepatan sesaat pada titik ini dapat dilakukan dengan dua cara yaitu lintasan pada alat menggunakan hukum kekekalan energi mekanik dan lintasan setelah jatuh yaitu gerak parabola.

Kecepatan ditinjau dari waktunya dibagi menjadi dua, yaitu kecepatan rata-rata dan kecepatan sesaat. Kecepatan rata-rata didefinisikan sebagai perbandingan antara perpindahan $\Delta x$ dan selang waktu $\Delta t=t_{2}-t_{1}$. Kecepatan suatu benda bergerak setiap waktu kadang berubah. Kecepatan rata-rata ini hanya mendiskripsikan secara keseluruhan sebuah sistem. Untuk menjelaskan kasus ini muncul istilah kecepatan sesaat yaitu kecepatan pada posisi tertentu yang memiliki waktu limit. Secara kualitatif dapat ditulis sebagai berikut: (Tipler, 1998)

$$
\lim _{\Delta t \rightarrow 0} \frac{\Delta x}{\Delta t}=\frac{d x}{d t}
$$

Sama seperti pada penetian sebelumnya titik kecepatan sesaat yang ditinjau adalah kecepatan saat bola akan jatuh dari ujung lintasan alat.
Begitupun cara dan perhitungan yang dilakukan sama dengan penelitian sebelumnya yang berkaitan dengan konsep fisika yaitu gerak parabola, hukum kekekalan energi mekanik. Adapun pembaharuan yang akan dilakukan adalah meninjau pengaruh kekasaran lintasan atau berkaitan dengan konsep gaya gesek.

\section{Gerak Parabola}

Gerak parabola adalah topik yang dipakai dalam pengajaran kinematika yang merupakan penggabungan antara gerak arah sumbu $x$ dan sumbu $y$. Asumsi yang banyak dipakai adalah gesekan udara diabaikan, meskipun kenyataannya gesekan sangat banyak berperan dalam mengurangi energi gerak benda yang akhirnya mengurangi ukuran trayektori proyektil. Perhitungan kinematika perlu dilengkapi lagi dengan dinamika dengan melibatkan massa dan gaya seretan udara. (Purwadi \& Ishafit, 2014)

Pada gerak proyektil tidak ada percepatan horizontal, maka komponen $x$ kecepatannya konstan,

$$
v_{y}=v_{0 x}
$$

Komponen $y$ berubah dengan waktu sesuai dengan

$$
v_{y}=v_{0 y}-g t
$$

Maka komponen perpindahan proyektilnya

$$
\begin{gathered}
\Delta x=v_{0 x} t \\
\Delta y=v_{0 y} t-\frac{1}{2} g t^{2}
\end{gathered}
$$

Dalam gerak peluru, apabila hambatan udara dan efek gerak perputaran bumi diabaikan, serta percepatan gravitasi dianggap tetap, maka komponen gaya yang bekerja hanyalah gaya gravitasi bumi yang dialami oleh benda atau yang seringkali disebut dengan gaya berat benda. Dalam kasus ini, gaya berat benda adalah konstan, baik besar maupun arahnya. (Supardi, 2011)

\section{Hukum Kekekalan Energi Mekanik}

Energi Mekanik dalam ilmu fisika." Energi tidak dapat diciptakan dan juga tidak dapat dimusnahkan". Jadi perubahan bentuk suatu 
energi dari bentuk yang satu ke bentuk yang lain dengan tidak merubah jumlah atau besar energi secara keseluruhan (Hukum kekekalan Energi). Di dalam ilmu fisika, kita tahu energi dapat digolongkan menjadi beberapa macam energi, diantaranya adalah energi mekanik (energi potensial+energi kinetik), energi panas, energi listrik, energi kimia,energi nuklir,energi cahaya, enrgi suara dan sebagainya. (Ariwibowo \& Desmira, 2016)

Hukum kekekalan energi mekanik membahas tentang perubahan bentuk energi dari energi potensial menjadi energi kinetik atau sebaliknya. Selama proses perubahan, bisa saja sebagian energi mekanik hilang karena friksi atau sebab yang lain (Prastowo, Cholifah, Puspitasari, \& Ain, 2016).

\section{Gaya Gesek}

Gesekan adalah persinggungan antara dua atau lebih dari suatu benda, gesekan ini akan menghasilkan gaya gesek. Gaya gesek dibagi menjadi dua yaitu gaya gesek statis dan gaya gesek kinetis. Gaya gesek statis adalah gaya-gaya gesek yang bekerja antara dua permukaan yang berada dalam keadaan relatif satu dengan yang lainnya. Sekali benda bergerak, gaya-gaya gesekan yang bekerja akan berkurang besarnya, dan yang bekerja adalah gaya gesek kinetis. Dari ini diketahui bahwa gaya gesek kinetis lebih kecil nilainya dari pada gaya gesek statis. (Rusmardi, 2008)

Pada kenyataannya besarnya gaya gesek kinetis sebanding dengan besarnya gaya normal $(N)$ yang

dikerjakan bidang terhadap benda dan tidak bergantung pada laju relatif benda terhadap bidang. Perbandingan gaya gesek kinetis terhadap gaya normal mempunyai nilai yang relatif konstan, dikenal dengan nama koefisien gesek kinetis $(\mu k)$. Nilai ini bergantung pada banyak variabel, seperti misalnya sifat-sifat bahan, pengolahan permukaan, lapisan permukaan, suhu, dan derajat pengotor. (Halliday
\& Resnik, Pantur Silaban Ph.D \& Drs. Erwin Sucipto, 1984)

Tujuan peneilian ini akan membandingkan hasil kecepatan sesaat dengan melakukan perhitungan dan grafik yang diperoleh dari analisis video tracker. Salanjutnya, membandingkan kecepatan sesaat yang diperoleh antara lintasan kasar dan lintasan licin. Hasil-hasil tersebut akan dianalisis untuk mengetahui pengaruh kecepatan sesaat serta penyebabnya.

\section{METODE PENELITIAN}

Metode penelitian yang digunakan adalah metode eksperimental dan analisis video melalui bantuan aplikasi tracker. Eksperimen menggunakan alat yang dibuat dengan derajat lengkungan mendekati 900 ( $1 / 4$ lingkaran). Bola pingpong sebagai bola tipis berongga menjadi tinjauan gerak yang melalui lintasan. Sistem pertama yaitu melapisi permukaan alat yang akan menjadi jalur bola dengan amplas sebagai lintasan kasar. Alat di tempatkan pada ketinggian tertentu dan bola dilepaskan pada titik puncak alat tanpa diberi kecepatan awal. Pergerakan bola direkam menggunakan video recorder handphone dari awal pelepasan bola hingga jatuh kedasar alas. Percobaan dilakukan sebanyak delapan kali dengan menandai tiap titik jatuh pertama kali bola ke dasar alas. Sistem kedua yaitu lintasan licin dengan menggunakan kertas nasi yang melapisi jalur lintasan bola. Setiap langkah percobaan sama dengan sistem lintasan kasar. Data-data yang diperoleh yaitu tinggi puncak alat (h1), tinggi alat kepermukaan alas $(\mathrm{H})$, titik-titik jatuh bola ke dasar alas (D) saat melintasi permukaan kasar dan permukaan licin. Selanjutnya diolah dan intrepretasikan sesuai dengan permasalahn penelitian. Analisis data penelitian menggunaan deskriptif non parametrik

\section{HASIL DAN PEMBAHASAN}

Untuk menguji kecepatan relatif sesaat melalui gerak parabola, disini kami menggunakan hukum kekekalan energi dan analisis video tracker 
seperti penelitian pada buku Experiment and Video Analysis in Classicsl Mechanics. Pada penelitian tersebut menguji kecepatan relatif sesaat dengan mengubah ketinggian, sedangkan penelitian yang kami lakukan mengubah permukaan lintasan menjadi lintasan licin dan lintasan kasar.

Dari penelitian yang telah dilakukan diperoleh data setiap variabel sebagai berikut:

Tabel 1 Data pada lintasan kasar dan lintasan

\begin{tabular}{lll}
\multicolumn{3}{c}{ licin } \\
\hline Variabel & Permukaan & Permukaan \\
& kasar & licin \\
$\mathrm{D}$ & $305 \times 10^{-3} \mathrm{~m}$ & $330 \times 10^{-3} \mathrm{~m}$ \\
$\mathrm{H}$ & $260 \times 10^{-3} \mathrm{~m}$ & $260 \times 10^{-3} \mathrm{~m}$ \\
$\mathrm{M}$ & $2,8 \times 10^{-3} \mathrm{~m}$ & $2,8 \times 10^{-3} \mathrm{~m}$ \\
$\mathrm{~h}$ & $535 \times 10^{-3} \mathrm{~m}$ & $535 \times 10^{-3} \mathrm{~m}$ \\
$\mathrm{R}$ & $19,6 \times 10^{-3} \mathrm{~m}$ & $19,6 \times 10^{-3} \mathrm{~m}$ \\
\hline
\end{tabular}

Keterangan

$\mathrm{D}=$ jarak ttitik o ketitik jatuh bola $(\mathrm{m})$

$\mathrm{H}=$ tinggi dasar alat kedasar titik $(\mathrm{m})$

$\mathrm{M}=$ massa bola $(\mathrm{kg})$

$\mathrm{h}=$ tinggi alat $(\mathrm{m})$

$\mathrm{R}=$ Jari-Jari bola

Berdasarkan data di atas, peneliti dapat melakukan perhitungan untuk mendapatkan nilai kecepatan sesaat dengan menggunakan persamaan :

$$
\begin{aligned}
D & =v_{0} t \\
H & =\frac{g t^{2}}{2}
\end{aligned}
$$

Persamaan (1) dieksplisitkan terhadap waktu dan mensubstitusikan ke persamaan (2), maka diperoleh:

$$
v_{0}=D \sqrt{\frac{g}{2 H}}
$$

Setelah melakukan perhitungan menggunakan persamaan (1), (2) dan (3) diperoleh nilai:

Saat bola berada di puncak energi mekanik yang diperoleh hanya diberikan oleh energi potensial gravitasi sedangkan pada saat di dasar alas energi mekanis yang diperoleh hanya diberikan oleh energi kinetiknya. Energi mekanik yang berada di puncak nilainya harus sama dengan energi mekanik yang berada di dasar alas sehingga persamaannya menjadi:

$$
\begin{aligned}
& \text { Energi kinetik }=\text { energi } \\
& \text { potensial } \\
& \quad \frac{1}{2} m v_{0}=m g h
\end{aligned}
$$

Dimana kecepatan pada titik $0\left(v_{0}\right)$

$$
v_{0}=\sqrt{2 g h}
$$

Dari persamaan (5) didapatkan

$$
v_{0}=1,082 \mathrm{~m} / \mathrm{s}
$$

Selanjutnya, metode analisis yang digunakan pada penelitian ini adalah menggunakan tracking video. Dengan menggunakan software tracker, dilakukan proses tracking untuk masing-masing video. Untuk menjaga ketepatan posisi penanda track maka tidak digunakan fitur autotracker, tetapi tracking dilakukan secara manual untuk setiap tracknya. Dari hasil tracking diperoleh data dari fungsi grafik jarak $(x)$ terhadap waktu $(t)$ seperti berikut:

1. Pada Permukaan Licin

Pada permukaan licin diperoleh data hasil tracking serta fungsi grafik perubahan posisi $(x)$ terhadap waktu $(t)$ dan fungsi grafik perubahan posisi $(x)$ terhadap waktu $(t)$ pada saat jatuh. Seperti pada gambar berikut:

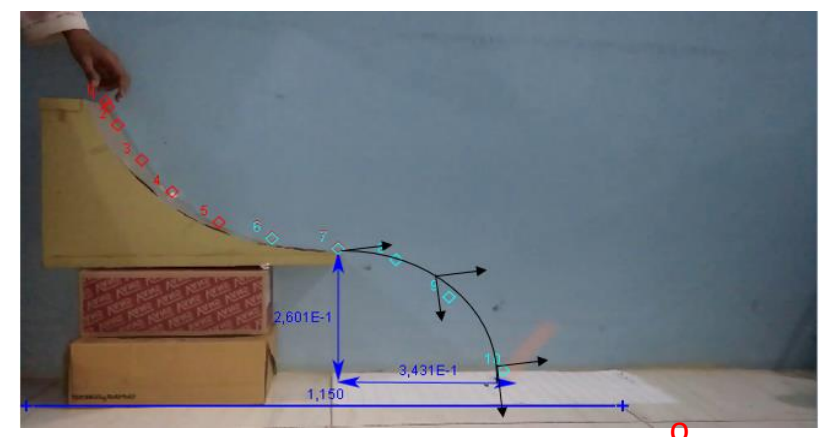

Gambar 1. Percobaan pada permukaan licin Dari gambar 1 menjelaskan terdapat dua keadaan, yaitu kecepatan pada saat bola menggelinding di permukaan licin dan kecepatan ketika bola jatuh yang dipengaruhi oleh gaya gravitasi, sehingga terjadi gerak parabola. Untuk mencari kecepatan bola ketika akan jatuh/ atau kecepatan titik $0\left(v_{0}\right)$ dapat melalui keadaan dua 
ini hasil tabel dan grafik pada keadaan dua tersebut:

Tabel 2. Data perubahan posisi $(x)$ terhadap waktu $(\mathrm{t})$ pada permukaan licin

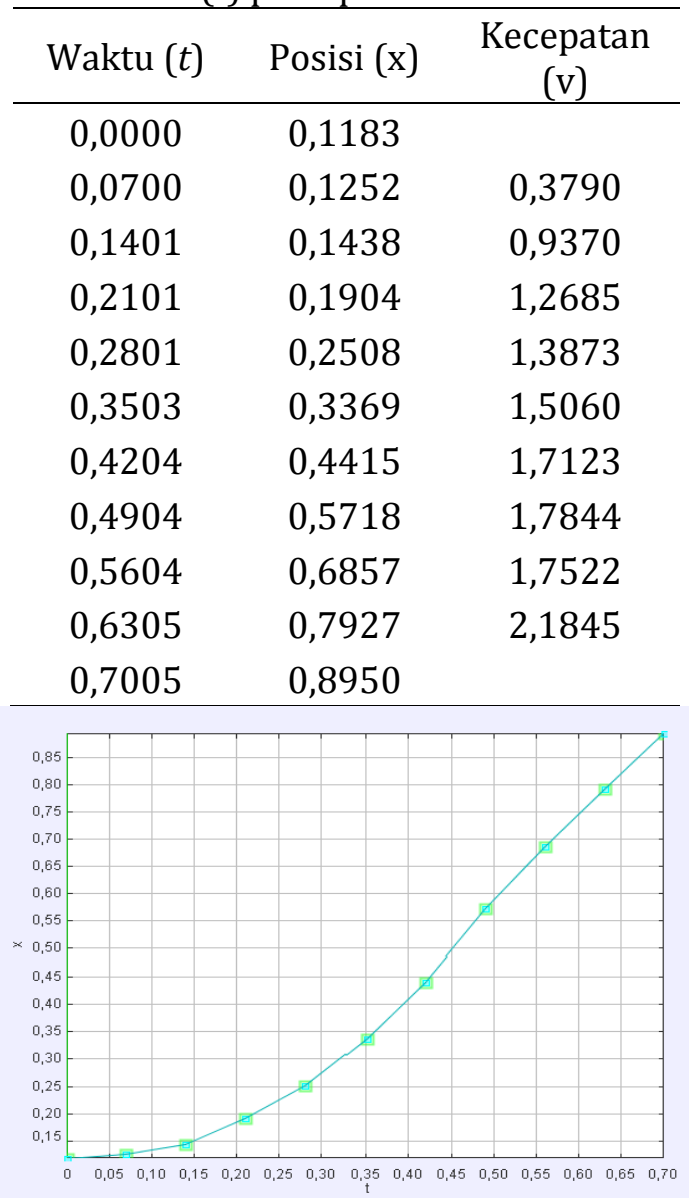

Gambar 1. Data perubahan posisi $(x)$ terhadap waktu $(\mathrm{t})$ pada permukaan licin

\section{Pada Permukaan Kasar}

Pada permukaan kasar diperoleh data hasil tracking serta fungsi grafik perubahan posisi $(x)$ terhadap waktu $(t)$ pada lintasan dan fungsi grafik perubahan posisi $(x)$ terhadap waktu $(t)$ pada saat jatuh. Sebagai berikut:

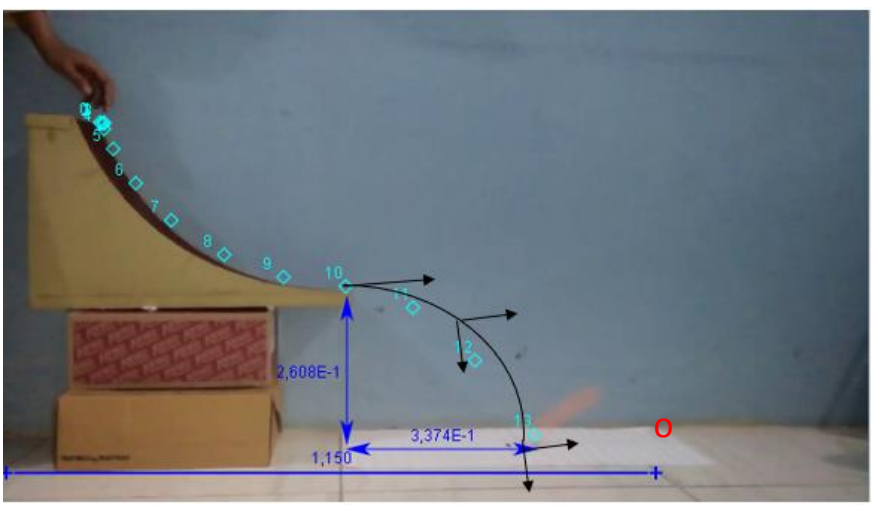

Gambar 2. Percobaan pada permukaan kasar

Dari gambar 2 menjelaskan terdapat dua keadaan, yaitu kecepatan pada saat bola menggelinding di permukaan kasar dan kecepatan ketika bola jatuh yang dipengaruhi oleh gaya gravitasi, sehingga terjadi gerak parabola Untuk mencari kecepatan bola ketika akan jatuh/ atau kecepatan titik $0\left(v_{0}\right)$ dapat melalui keadaan dua ini hasil tabel dan grafik pada keadaan dua tersebut:

Tabel 3. Hubungan perubahan posisi $(x)$ terhadap waktu $(\mathrm{t})$ pada permukaan kasar

\begin{tabular}{ccc}
\hline Waktu $(t)$ & Posisi $(\mathrm{x})$ & Kecepatan $(\mathrm{v})$ \\
\hline 0,000 & 0,094 & \\
0,070 & 0,101 & 0,024 \\
0,140 & 0,096 & 0,017 \\
0,210 & 0,101 & 0,075 \\
0,280 & 0,101 & 0,338 \\
0,350 & 0,117 & 0,794 \\
0,420 & 0,157 & 1,163 \\
0,490 & 0,220 & 1,437 \\
0,560 & 0,314 & 1,592 \\
0,630 & 0,419 & 1,589 \\
0,701 & 0,529 & 1,682 \\
0,771 & 0,649 & 1,886 \\
0,841 & 0,759 & 2,222 \\
0,911 & 0,864 & \\
\hline
\end{tabular}




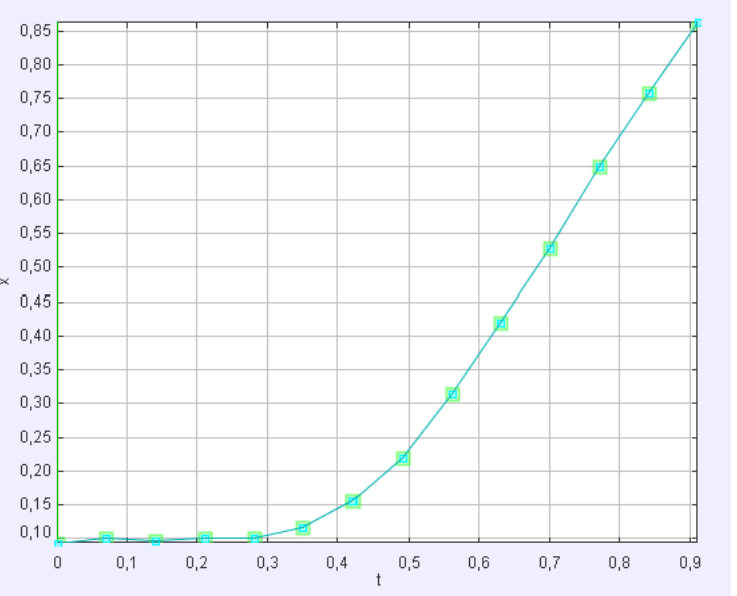

Gambar 2. Hubungan perubahan posisi $(x)$ terhadap waktu $(\mathrm{t})$ pada permukaan kasar

Kecepatan sesaat pada proser diatas ditunjukan pada tabel dibawah ini:

Tabel 4. Kecepatan benda pada berbagai

\begin{tabular}{ccc}
\multicolumn{3}{c}{ permukaan } \\
\hline Proses & Kasar & Licin \\
\hline Gerak & $1,323 \mathrm{~m} / \mathrm{s}$ & $1,431 \mathrm{~m} / \mathrm{s}$ \\
Parabola & & \\
Energi mekani & $1,082 \mathrm{~m} / \mathrm{s}$ & $1,082 \mathrm{~m} / \mathrm{s}$ \\
Tracker & $1,589 \mathrm{~m} / \mathrm{s}$ & $1,712 \mathrm{~m} / \mathrm{s}$ \\
\hline
\end{tabular}

Pada tabel diatas menunjukan bahwa kecepatan sesaat pada permukaan licin menggunakan gerak parabola dan hukum kekekalan energi mekanika yaitu $1,323 \mathrm{~m} / \mathrm{s}$ dan $1,808 \mathrm{~m} / \mathrm{s}$. Sedangkan untuk menggunkan tacker diperoleh $1,712 \mathrm{~m} / \mathrm{s}$. Perbedaan ini dapat terjadi. Hasil ini menunjukan bahwa pada sistem perhitungan gerak parabola lebih mendekati pada perhitungan tracker ketimbang menggunakan sistem energi mekanik. Hal ini bisa terjadi karena pada proses energi mekanik meggunakan lintasan lengkung yang menyebabkan terjadinya kemungkinan yaitu, sudutnya selalu berubah.

Untuk permukaan kasar menggunakan gerak parabola dan hukum kekekalan energi mekanika yaitu $1,431 \mathrm{~m} / \mathrm{s}$ dan $1,082 \mathrm{~m} / \mathrm{s}$. Sedangkan untuk menggunkan tacker diperoleh 1,589 m/s. Ketiga nilai memiliki rentang yang tidak terlalu jauh. Adapun untuk perbandingan kecepatan sesaat pada lintasan licin dan lintasan kasar, secara perhitungan lintasan kasar memiliki nilai yang lebih besar dari pada lintasan licin. Tetapi pada tracker lintasan licin lebih besar daripada lintasan kasar. Sehingga perbedaan ini dikarenakan saat menggunakan tracker pada masing-masing video harus tepat posisinya ketika melakukan proses tracking.

\section{KESIMPULAN}

Dari penelitian yang telah dilakukan ini dapat diambil kesimpulan bahwa penerapan metode tracking video menggunakan software tracker dan secara perhitungan untuk menentukan nilai kecepatan sesaat pada lintasan yang berbeda telah berhasil dilakukan. Nilai kecepatan sesaat pada lintasan yang licin lebih besar dari pada pada lintasan kasar. Dengan nilai kecepatan sesaat pada gerak parabola di lintasan licin adalah $1,431 \mathrm{~m} / \mathrm{s}$ dan di lintasan kasar adalah 1,323 m/s. Sedangkan dengan menggunakan tracker nilai kecepatan sesaat pada gerak parabola di lintasan licin adalah $1,712 \mathrm{~m} / \mathrm{s}$ dan di lintasan kasar adalah $1,589 \mathrm{~m} / \mathrm{s}$.

\section{DAFTAR PUSTAKA}

Ariwibowo, D., \& Desmira. (2016). Pengembangan Aplikasi Simulasi Perhitungan Energi Mekanika Berdasarkan Hukum Kekekalan Energi dalam Proses Belajar Siswa. Jurnal Prosisko, 12-16.

Halliday \& Resnik, Pantur Silaban Ph.D \& Drs. Erwin Sucipto. (1984). Fisika Untuk Universitas, Edisi ktiga, jilid 1. Jakarta: Erlangga.

Prastowo, T., Cholifah, L., Puspitasari, A. D., \& Ain, N. T. (2016). Uji Hukum Kekekalan Energi Mekanik pada Sistem Dua Fluida. Uji Hukum Kekekalan Energi Mekanik pada Sistem Dua Fluida, 115-118.

Purwadi, \& Ishafit. (2014). Pemodelan Gerak Parabola yang Dipengaruhi Seretan serta Spin Efek Magnus Bola denga Program Modellus dan Excell. JRKPF, 11-18. 
Rusmardi. (2008). Analisis Percobaan Gesekan (Friction) untuk Pengembangan Teknologi Pengereman pada Kendaraan Bermotor. Jurnal Ilmiah Poli Rekayasa, 81-89.

Supardi, H. A. (2011). Telaah Gerak Parabol: Sifat Ellips dalam Gerak Parabola. Prosiding Simposium Nasional Pembelajaran dan Sains, 212-214.

Tipler, P. A. (1998). Fisika Untuk Sains dan Teknik. Jakarta: Erlangga. 